Cancer letters 2005

\title{
Differences in cell proliferation in rodent and human hepatic derived cell lines exposed to ciprofibrate.
}

Marie-Claude Clemencet ${ }^{\mathrm{a}}$, Giuliana Muzio $^{c}$, A. Trombetta ${ }^{c}$, J.M. Peters ${ }^{\mathrm{b}}$, F.J. Gonzalez ${ }^{\mathrm{b}}$, Rosangela A. Canuto ${ }^{c} \&$ Norbert Latruffe $^{\mathrm{a}}$

${ }^{1}$ University of Burgundy, LBMC (GDR-CNRS n²583), 6, bd Gabriel 21000 Dijon France

${ }^{2}$ NIH Laboratory of metabolism, Bethesda, USA

${ }^{3}$ University of Torino, Dept of Medicine and experimental oncology, 10125 Torino, Italy

Correspondence to

$\operatorname{Pr}$ N. LATRUFFE

Université de Bourgogne

Laboratoire de Biologie Moléculaire et Cellulaire

(EA 2978-GDR-CNRS n'2583)

Faculté des Sciences Gabriel

6, bd Gabriel 21000 Dijon France

Tel (33) $380396236-f a x:$ (33) 380396250

mel: norbert.latruffe@u-bourgogne.fr 


\section{Abstract}

Peroxisome proliferators are widely used in different countries, especially in industrialized nations since they include hypolipidaemic agents of the fibrate family, plasticizers, herbicides as well as some solvents and pain additives. Human beings appear to be refractory to some effects of peroxisome proliferators activating peroxisome proliferator-activated receptor alpha (PPARalpha). Data from clinical trials and epidemiological studies do not demonstrate or rule out a human health risk associated with exposure to peroxisome proliferators. On the contrary rodents appear more susceptible to both carcinogenic and toxic effect of these peroxisome proliferators. In this study the possible differences between human and rat species has been evaluated examining the cell proliferative response to peroxisome proliferators by using rat and human tumour liver cell lines. A species difference in the response to peroxisome proliferators was observed. Rat 7777 hepatoma cells are more responsive than human HepG2 hepatoblastoma cells to ciprofibrate: 7777 cells show a higher decrease in cell number than HepG2 cells. Moreover, ciprofibrate is more toxic towards 7777 than to HepG2 cells: 7777 cells undergo apoptosis, whereas this does not happen to HepG2 cells. Oncogene c-myc is involved in both proliferation and apoptosis, but in opposite way where it decreases during proliferation reduction and increases during apoptotic process. Modulation of c-myc expression is controlled by PPARalpha as also demonstrated by increase lack of mRNA level in liver from Wy 14,643-treated PPARalpha-null mice. Moreover, the growth decrease is correlated with an increase of cells in G0/G1 phase, and a decrease of level of phosphorylated form of Erk1 and Erk2, whereas the of apoptosis increase with an increase of cells in $\mathrm{S}$ phase. These data provide evidence for a species difference between rodent and human liver cell lines in response to peroxisome proliferators. They are consistent with the idea that human cells are more refractory than rodent cells.

Key words : peroxisome proliferators; peroxisome proliferator-activated receptor alpha (PPARalpha), species difference; c-myc; human hepatoma cells; rat hepatoma cells, proliferation; apoptosis 


\section{Introduction}

Numerous chemical molecules belonging to the peroxisome proliferators class of chemicals are present in the environment, increasing the risk of humans exposure $[1,2]$. Some of these chemicals are produced annually in high amounts by agro/pharma chemical industries, like plasticizers (adipates, phthalates), herbicides (chlorinated phenoxyacetates), paint solvents and anticorrosive additives (perfluoroacids). Fibrates are produced in smaller amounts but are frequently used as prescription drugs to prevent cardiovascular diseases decreasing serum lipids. Prolonged administration of peroxisome proliferators causes liver cancer in rodents [1], and the experimental evidence for this adverse effect in humans exposed to these chemicals is inconclusive [3]. In rodents, peroxisome proliferation is one indicator of exposure and possibly linked to the carcinogenic mechanisms since it may lead to an overproduction of intracellular $\mathrm{H}_{2} \mathrm{O}_{2}$, a reactive oxygen species [4]. This event is mediated by PPARalpha, an isotype of the PPAR family which is activated by these xenobiotics [5] and modulates the expression of various genes that regulate lipid metabolism including those involved in fatty acid beta-oxidation [6,7] and omega-oxidation (cytochrome P4504A). Anyway the mechanisms of peroxisome proliferator-induced hepatocarcinogenesis in rodents are not completely understood and could include alterations in cell proliferation and apoptosis (for recent reviews see, 8-11). To evaluate the potential human risk, molecular targets must be identified through experiments in animals as well as by using in vitro systems to elucidate the possible mechanisms. The use of in vitro systems revealed that peroxisome proliferators can be toxic in relation to the concentrations used. Several groups have shown that peroxisome proliferators at low concentration $(0.05 \mathrm{mM})$ can suppress hepatocyte apoptosis that may normally act to remove damaged or excess cells from the liver [12-15]. Additionally, there is evidence that peroxisome proliferators at the same concentration induce increased replicative DNA synthesis and cell proliferation in rodent hepatocytes [16]. On the contrary, at higher concentrations than $0.05 \mathrm{mM}$ peroxisome proliferators are toxic on tumour rodent cells, causing an increase of cells dead by apoptosis [17-19]. A comparison between rodent and human cell lines provides a good model to examine the molecular events induced by peroxisome proliferators to determine if there are species differences. For this reason in this study, c-myc oncogene expression and markers of cell proliferation were examined in rodent and human liver cell lines. The cellular oncogene $c-m y c$ encodes a nuclear transcription factor involved in both normal and 
dysregulated cell division, and/or in apoptotic process. Previous work has shown that hepatic c-myc (or N-myc) mRNA level is increased in rodents treated with peroxisome proliferators [20-24]. More recently, it was reported that c-myc gene expression is dependent on the PPARalpha since PPARalpha null mice are refractory to induction of $c$-myc liver oncogene after treatment with a peroxisome proliferator [23]. Further support for a direct role of the PPAR in the regulation of c-myc gene expression was provided by the observation that mouse $\mathrm{N}$-myc promoter contains a putative peroxisome proliferator response element (PPRE) [24]. PPARalpha highly expressed in the liver, other than in promoting fatty acid catabolism [25] is involved in several other functions, for example in cell cycle progression, in differentiation and death [26-27,28].

The goals of this study were: 1) to examine the effect of ciprofibrate, a peroxisome proliferator and hypolipideamic drug, on proliferation and death of tumour cell lines derived from human (HepG2 cells) or from rat liver (7777); 2) to estimate the correlation between c-myc and PPARalpha expression in hepatoma cell lines treated with ciprofibrate and in PPARalpha null-mice treated with Wy 14,643; 3, another potent peroxisome proliferator) to determine the effect of peroxisome proliferators on MAP kinase (Erk 1 and Erk 2) phosphorylated level.

\section{Material and methods}

\subsection{Materials}

Wy 14,643 and ciprofibrate (Figure 1) were purchased from Sigma (St. Louis, MO, USA), and Sanofi-Winthrop, respectively. Specific antibodies against PPARalpha, Erk 1 and 2 (phosphorylated and non-phosphorylated forms), and c-myc were purchased from Santa Cruz Biotechnology Inc. California. All culture media and reagents were purchased from Sigma.

\subsubsection{Culture conditions and treatments}

Rat hepatoma 7777 cells were seeded $\left(20000\right.$ cells $\left./ \mathrm{cm}^{2}\right)$ and maintained in DMEM/F12 medium plus $2 \mathrm{mM}$ glutamine, 1\% antibiotic/antimycotic solution and $10 \%$ newborn calf serum. Human HepG2 hepatoblastoma cells were seeded (50000 cells $/ \mathrm{cm}^{2}$ ) and maintained in MEM medium plus $2 \mathrm{mM}$ glutamine, $1 \%$ antibiotic/antimycotic solution and 10\% foetal bovine serum. $24 \mathrm{~h}$ after cell seeding, 7777 and HepG2 cells were treated with ciprofibrate, dissolved in DMSO $(<0.05 \%$ final 
volume), at concentrations of $0.05,0.1,0.20,0.5$ or $1 \mathrm{mM}$ and harvested at 4,24 and $48 \mathrm{~h}$. 


\subsubsection{PPARalpha-null mice}

PPAR alpha (-/-) male mice on an Sv/129 background, generated according to Lee et al, 1995 were housed 4-5 animals per cage in a temperature -and light controlled environment $\left(\mathrm{T}=25^{\circ} \mathrm{C}, 12 \mathrm{~h}\right.$ light/dark cycle). Wild and PPARalpha null mice were fed with or without $0.1 \% \mathrm{Wy}-14,643$ for 2 weeks

\subsubsection{Cell proliferation}

Cell proliferation was evaluated as the number of cells present in the monolayer and in the culture medium. Cell numbers were determined by using a Bürker chamber.

\subsubsection{Lactate dehydrogenase activity}

Lactate dehydrogenase activity (LDH) was determined in the culture medium by spectrophotometric assay and was expressed as nmoles of NADH consumed/ml of medium [29].

\subsubsection{Fluorescence microscopy}

Cells were fixed in methanol, stained with the DNA-specific fluorochrome DAPI and examined under an epiilluminated fluorescence microscope (Dialux, Leitz, Germany). The apoptotic index (percentage of apoptotic cells) was determined on at least 1000 cells per sample.

\subsubsection{DNA distribution}

The percentages of cells in different phases of the cell cycle and the percentage of cells present of subG0/G1 peak were evaluated by flow cytometry determining the DNA content after propidium iodide staining, as described elsewhere [30]. The percentages are calculated respect to total counted cells.

\subsection{Northern Blotting}

After RNA extraction, northern blotting was performed using appropriated 32P labelled probes (using random priming method). The human c-myc cDNA (Oncor product) for human RNA hybridizations, murine c-myc cDNA [31] for mouse RNA hybridizations, mouse peroxisomal acyl-CoA oxidase cDNA for all blots [20], and human $ß$-actin cDNA as a control for all blots. Autoradiographs were scanned with a densitometer and relative hybridisation signals were calculated based on the percentage of the beta-actin signal. 


\subsubsection{Western Blot analysis}

Cellular extracts were prepared as described in [31] and blotted with polyclonal anti-PPARalpha, anti-pErk 1,2 (phosphorylated form), anti Erk 1,2 (unphosphorylated form) or anti-c-myc antibodies. For determination of the content of PPARalpha protein in HepG2, immunoprecipitation was used.

\subsubsection{Protein determination}

Protein content was determined by the Protein Assay Kit 2 (Bio-Rad Laboratory, Inc.).

\subsubsection{Statistical analysis}

All data were expressed as means \pm S.D. Significant differences between group means were determined by analysis of variance, followed by the Newman-Keuls test.

\section{Results}

\subsection{Cell growth of human and rat hepatoma cells exposed to ciprofibrate.}

The effect of ciprofibrate on human HepG2 hepatoblastoma and rat 7777 hepatoma cell proliferation was examined. The former cells exhibited a decrease in proliferation upon culture in $0.25 \mathrm{mM}$ ciprofibrate (Fig. 2A) starting from $24 \mathrm{~h}$ treatment, whereas this effect was not observed at the lower concentrations. To compare this inhibitory effect found in human HepG2 cells with rat hepatoma cells, the effect of ciprofibrate on cell proliferation was examined in rat 7777 hepatoma cell line (Fig. 2B). Cell proliferation was significantly reduced as a result of ciprofibrate treatment in this rat hepatoma cell line, and this effect was more pronounced compared to HepG2 cells in the presence of the highest concentrations, especially at $48 \mathrm{~h}$ treatment. For example with $1 \mathrm{mM}$ ciprofibrate at $48 \mathrm{~h}$ exposure, inhibition of cell proliferation was $68 \%$ for rat 7777 hepatoma cells, whereas it was only $43 \%$ for HepG2 cells. Inhibition of HepG2 cell proliferation by ciprofibrate was not due to cytotoxicity, as detached cells were not found in the medium, and lactate dehydrogenase activity in the medium was identical to that of the control cells (data not shown). Moreover, the presence of apoptotic cells, as determined by staining the cells with DAPI and by examining them with flow 
cytometry (Table 1), showed very low percentage after $48 \mathrm{~h}$ exposure (for HepG2 cells). In contrast, for rat 7777 hepatoma cells at $48 \mathrm{~h}$ exposure there was $10 \%$ of cells detached from the monolayer, and all detached cells were undergoing apoptosis, as determined by evaluating the presence of sub G0/G1 peak by flow cytometry. Also in the monolayers of 7777 cells exposed for $48 \mathrm{~h}$ to 0.5 or $1 \mathrm{mM}$ ciprofibrate, apoptotic cells were present and their percentages were 29 and $37 \%$, respectively (Table 1). These results confirm that human HepG2 cells are more resistant to ciprofibrate than rat hepatoma cells. In fact, ciprofibrate is not cytotoxic on HepG2 cells, whereas it is on rat hepatoma cells.

To identify the phase of the cell cycle that was changed in response to ciprofibrate, the DNA content was determined by flow cytometry in HepG2 and in 7777 cells after treatment with. Results from this analysis indicate that in HepG2 cells ciprofibrate decreases cell growth by causing a block in the G0/G1 phase, and a decrease in the cells entering the S phase (Fig.3), whereas in 7777 cells it increases the percentage of cells counted in S phase, more markedly at 48 hours (Fig.4).

Consistent with the decrease of cell growth, in HepG2 cells there is a decrease in phosphorylated form of Erk (a MAP kinase subunit and a key component of the mitogen signaling pathway), without changing the total Erk 1,2 protein content (Fig. 5).

\section{2. c-myc and PPARalpha gene expression in in human and rat hepatoma cells and in PPARalpha-null mice}

Due to the role played by c-myc oncogene, in the cell proliferation control our interest, in studying the modulation of c-myc level in hepatoma cells treated with peroxisome proliferators, prompted us to examine the correlation between c-myc and PPARalpha expression both in vitro, in human and rodent hepatoma cell lines, and in vivo, in PPARalpha-null mice. In human HepG2 cells, ciprofibrate decreases both cmyc and PPARalpha protein content at all experimental times considered (Fig.6A), being the more marked reduction evident in c-myc content at $48 \mathrm{~h}$ exposure (inhibition percentage 55\%). In rat 7777 cells (Fig.6B), ciprofibrate shows opposite effect at 24 or $48 \mathrm{~h}$ exposure; in fact, at $24 \mathrm{~h}$ a strong reduction of both c-myc (-75\%) and PPARalpha $(-45 \%)$ protein occurs, whereas at $48 \mathrm{~h}$ c-myc protein increases almost three times and PPARalpha more than eight times.

Fig. 7A shows that treatment with Wy114,643 (another peroxisome proliferators with similar effects than ciprofibrate) for 10 days results in a 4 -fold increase of c-myc mRNA in wild-type mice compared to untreated wild type mice, whereas this effect is 
largely diminished in PPARalpha-null mice. As positive controls hepatic levels of mRNA for PPARalpha and peroxisomal AOX are induced by Wy 14,643 in wild-type mice, and this effect is absent in PPARalpha-null mice (Fig7B). 


\section{Discussion}

Since the mechanisms underlying the putative species differences in the response to peroxisome proliferators are not well characterized, in this study, a comparative molecular analysis on hepatic derived cells of both human and rodent species was performed.

\subsection{Cell growh}

Significant species differences in the effect of peroxisome proliferators on liver mass is also known to exist [32,33]. By measuring the hepatosomatic index of three species treated at a dose of ciprofibrate resulting in the same plasma level of the drug, (thus at the pharmacoequivalence to tissues), an increase in liver weight is only observed in the treated rat, while no significant change in liver weight is found in the jerboa [34] or guinea pig [35]. Our in vitro study comparing the responsiveness of human and rat hepatoma cells to ciprofibrate also showed differences: the growth of both types of cells from different species is negatively regulated by ciprofibrate, but less in human hepatoma cells. The more marked reduction of cell number occurring in rat cells is evident in presence of 0.5 and $1 \mathrm{mM}$ ciprofibrate at 24 and $48 \mathrm{~h}$ exposure. Moreover, in the human cells the reduction of cell number is not due to the appearance of cell death, like as in rat hepatoma cells, where a massive apoptosis occurs at $48 \mathrm{~h}$ exposure in presence of $0.5 \mathrm{mM}$ ciprofibrate. The susceptibility to apoptosis showed by rat 7777 hepatoma cells is in agreement with previous reported data on another rat hepatoma cell line, Fao cells. In fact, these cells exposed to ciprofibrate and analysed by flow cytometry show modifications of intrinsic cellular parameters, such as size and cytoplasmic granularity, indicating the occurrence of apoptotic death. In the same study in ciprofibrate-treated HepG2 cells no apoptosis was observed [36]. It is to note that in this previous study the concentration of ciprofibrate used was not up $0.2 \mathrm{mM}$; whereas in the present study higher concentrations were used.

A different response between human and rat tumour cells is also evident in the distribution of cells in the different phases of cycle. In fact, in HepG2 cells the reduced cell growth corresponds to an increased population in G0/G2 phase; whereas in 7777 cells the induction of apoptosis correspond to an increased percentage of cells in $\mathrm{S}$ phase. We observed that also in presence of clofibrate, another peroxisome proliferators, 7777 cells are blocked in S phase and undergo apoptosis (unpublished 
data). In the same way, a previous study on the cell cycle distribution of asynchronously growing rat Fao cells showed an increase in the percentage of proliferative cells in ciprofibrate-treated cells [37].

\subsection{Correlation between c-myc oncogene expression and PPARalpha}

It is well known that oncogenes are involved in some effects of peroxisome proliferators. The oncogenes c-myc or $\mathrm{N}$-myc encoding for transcription factors have an essential role in the rodent carcinogenic process involving peroxisome proliferators [20, $37,21,38]$. Other oncogenes may also be involved $[16,20,37,21,39,38]$ as well as key proteins of the cell cycle [40]. We have shown [24] that overexpression of c-myc occurs in liver of rats treated with either clofibrate or ciprofibrate for a short (two weeks) or a long duration of time (one year). This effect is relatively liver specific since only a small c-myc mRNA level increase is found in kidney and no effect is observed in brain or heart [20].

In this study, we show that in HepG2 hepatoblastoma cells c-myc expression is negatively regulated by ciprofibrate at all experimental times considered, whereas in rat 7777 hepatoma cells, the regulation is negative during the first $24 \mathrm{~h}$ exposure, but becomes positive at the next experimental time. This different effect during the time could be related to the fact that in the first $24 \mathrm{~h}$ exposure 7777 cells undergo only a decrease in cell proliferation, whereas in the following time they show apoptotic death. The c-myc variations in both human and rat cell lines show the same behaviour than those of PPARalpha.

The transcription of some oncogenes might be PPAR dependent, since several oncogenes have a putative PPRE [24], in particular the mouse N-myc which shows an almost canonic sequence at the promoter region, as well as at the c-sis (related to betachain of PDGF) upstream sequence. Some PPRE-related sequences have also been found in other genes encoding proteins involved in carcinogenesis or cell proliferation: human v-raf, human and mouse p53, human c-fos, rat carcinogenic antigen, human cfms or chicken TGFbeta 3 gene [24]. Here, we show that the stimulation of c-myc expression by peroxisome proliferators is dependent on PPARalpha since the stimulation is largely abolished in liver from Wy 14,643-treated PPARalpha-null mice, which is consistent with a previous report [41]. Enhancement of c-myc expression is also increased in AOX-null mice that spontaneously develop liver tumours (unpublished observation), which is of interest since PPARalpha expression is higher compared to wild-type animals $[42,43]$. Moreover, in this research it has been shown that, at high 
concentrations of ciprofibrate $(>0.5 \mathrm{mM})$, induction of apoptosis is associated with cmyc and PPARalpha increased expression, whereas inhibited cell proliferation is associated with slightly lower PPARalpha and c-myc expression.

\subsection{Species difference}

The mechanisms underlying the species difference might be due to the lack or to different intermediate metabolic steps in non-responsive species. For example, it is likely that there are differences in xenobiotic metabolism and pharmacokinetics between highly and weakly responsive species. Indeed, ciprofibrate is cleared at a much higher in guinea pig than in rat [35]. The species differences might also be due in part to relatively lower levels of hepatic PPARalpha which is very low in liver cells of nonresponsive species when compared to rat and mice the high response species [44]. In rat, the PPARalpha tissue distribution shows the highest expression in liver as compared to other tissues [45] which is consistent with the lack of tumor formation in extrahepatic tissues of rodents triggered by peroxisome proliferators. In the human and rat cultured cells we used there is also difference in the content of PPARalpha; in fact, in HepG2 cells immunoprecipitation needed to be used to evidence it. The less content of PPARalpha protein could explain the more resistance of HepG2 to toxic effect of ciprofibrate.

In conclusion, our present work reports a species difference response of c-myc expression after peroxisome proliferator exposure at the last experimental time; moreover, we confirm that modulation of c-myc expression by peroxisome proliferators is dependent on PPARalpha, since its stimulation is partially abolished in liver from Wy 14,643-treated PPARalpha-null mice. In a previous report, Peters et al [41] demonstrated that c-myc activation is completely dependent on the PPARalpha since PPARalpha-null mice were refractory to the increase of this mRNA after exposure to Wy 14,643 for either 5 weeks or 11 months. In the present study, exposure to Wy 14,643 was limited to 10 days.

The resistance of human HepG2 cells towards peroxisome proliferators is explained by the different response to ciprofibrate in comparison with rat cells. At the present time of knowledge, our data are consistent with the idea that peroxisome proliferators represent a low, or no risk to humans. 


\section{Acknowledgements}

We thank the "Ligue Bourguignonne contre le Cancer" for its continuous support, the CNRS-GDR n ${ }^{\circ} 258$ on peroxisomes, IFR n92, Dr P. Passilly-Degrace, Dijon for cell cultures and Prof JK Reddy, Northwestern University, Dept. of Pathology, Chicago USA for his advises and informations on AOX-null mice. This study was also supported by grants from the Italian Ministry for University, Scientific and Technological Research (60\% and Cofinanziamento 1999, Compania San Paolo, Torino). 


\section{References}

[1] J.K. Reddy, N.D. Lalwani, Carcinogenesis by hepatic peroxisome proliferators: evaluation of the risk of hypolipidemic drugs and industrial plasticizers to humans. Crit Rev Toxicol. 12 (1983) 1-58.

[2] P. Bentley, I. Calder, C. Elcombe, Hepatic peroxisome proliferation in rodents and its significance for humans. Food Chem Toxic. 31 (1993) 857-907.

[3] F.J. Gonzalez, J.M. Peters, R.C. Cattley, Mechanism of action of the nongenotoxic peroxisome proliferator. Role of the peroxisome proliferator-activated receptor alpha J. Nat. Canc. Inst. 90 (1998) 1702-1709.

[4] C. Diez-Fernandez, N. Sanz, A.M. Alvarez, A. Wolf, M. Casales, The effect of nongenotoxic carcinogens, phenobarbital and clofibrate on the relationship between reactive oxygen species antioxidant enzymes expression and apoptosis. Carcinogenesis. 19 (1998) 1715-1722.

[5] I. Issemann, S. Green, Activation of a member of the steroid hormone receptor superfamily by peroxisome proliferators. Nature. 347 (1990) 645-650.

[6] K. Motojima, P. Passilly, J.M. Peters, F.J. Gonzalez, N. Latruffe, Expression of putative fatty acid transpoter genes are regulated by peroxisome proliferatoractivated receptor alpha and gamma activators in a tissue and inducer specific manner. J. Biol. Chem. 273 (1998) 16710-16714.

[7] J. Vamecq, N. Latruffe, Medical significance of peroxisome proliferator-activated receptors. Lancet. 353 (1999) 141-148.

[8] S.M. Cohen, M.E. Meek, J.E. Klaunig, D.E. Patton, P.A. Fenner-Crisp, The human relevance of information on carcinogenic modes of action: overview. Crit Rev Toxicol. 33 (2003) 581-9.

[9] V.G. Keshamouni, R.C. Reddy, D.A. Arenberg, B. Joel, V.J. Thannickal, G.P. Kalemkerian, T.J. Standiford, Peroxisome proliferator-activated receptor-gamma activation inhibits tumor progression in non-small-cell lung cancer. Oncogene. 23 (2004) 100-8.

[10] J.E. Klaunig, M.A. Babich, K.P. Baetcke, J.C. Cook, J.C. Corton, R.M. David, J.G. DeLuca, D.Y. Lai, R.H. McKee, J.M. Peters, R.A. Roberts, P.A. Fenner-Crisp, PPARalpha agonist-induced rodent tumors: modes of action and human relevance. Crit Rev Toxicol. 33 (2003) 655-780. 
[11] L. Michalik, B. Desvergne, W. Wahli, Peroxisome-proliferator-activated receptors and cancers: complex stories. Nat Rev Cancer. 4 (2004) 61-70.

[12] A.C. Bayly, R.A. Roberts, C. Dive, Suppression of liver cell apoptosis in vitro by the non-genotoxic hepatocarcinogen and peroxisome proliferator nafenopin. J. Cell Biol. 125 (1994) 197-203.

[13] J.H. Gill, C.A. Molloy, K. Shoesmith, A.C. Bayly, R.A. Roberts, The rodent nongenotoxic hepatocarcinogen Nafenopin and EGF after the mitosis/apoptosis balance promoting hepatoma cell clonal growth. Cell Death Diff. 2 (1995) 211217.

[14] A.C. Bayly, R.A. Roberts, C. Dive, Mechanisms of apoptosis. In "Adv. Mol. Cell Biol.: mechanisms of cell toxicity, pp 183-229 (EE Bittar \& KC Chipman eds), (1997) London, JAI press inc 11.

[15] J.G. Christensen, A.J. Gonzalez, R.C. Cattley, T.L. Goldsworthy, Regulation of apoptosis in mouse hepatocytes and alteration of apoptosis by non genotoxic carcinogens. Cell Growth Diff. 9 (1988) 815-825.

[16] P. Bentley, F. Bieri, S. Muakkassak-Kelly, Mechanisms of tumor induction by peroxisome proliferators. Arch Toxicol suppl. 12 (1988) 240-247.

[17] R.A. Canuto, G. Muzio, M. Maggiora, R. Autelli, G. Barbiero, P. Costelli, G. Bonelli, F.M. Baccino, Rapid and extensive lethal action of clofibrate on hepatoma cells in vitro. Cell Death Diff. 4 (1997) 224-232.

[18] R.A. Canuto, G. Muzio, G. Bonelli, M. Maggiora, R. Autelli, G. Barbiero, P. Costelli, O. Brossa, F.M. Baccino, Peroxisome proliferators induce apoptosis in hepatoma cells. Cancer Detect Prev. 22 (1998) 357-366

[19] R.A. Canuto, G. Muzio, G. Bonelli, M. Maggiora, A. Trombetta, G. Martinasso, R. Autelli, P. Costelli, G. Bonelli, F.M. Baccino, Apoptosis induced by clofibrate in Yoshida AH-130 hepatoma cells: role of HMG-CoA reductase. J Lipid Res. 44 (2003) 56-64.

[20] M. Cherkaoui Malki, Y.C. Lone, M. Corral-Debrinski, N. Latruffe, (1990) Differential proto-oncogene mRNA expression from rats treated with peroxisome proliferators. Biochem. Biophys. Res. Commun. 173 (1990) 855-861

[21] O. Bardot, M.-C. Clemencet, M. Cherkaoui Malki, N. Latruffe, Delayed effect of ciprofibrate on rat liver peroxisomal properties and proto-oncogene expression. Biochem. Pharmacol. 50 (1995) 1001-1006. 
[22] R.T. Miller, R.C. Cattley, D.S. Marsman, O. Lyght, J.A. Popp, TGF alpha differentially expressed in liver foci induced by diethylnitrosamine initiation and peroxisome proliferator promotion. Carcinogenesis. 16 (1995) 77-82

[23] J.M. Peters, N. Hennuyers, B. Stael, J.-C. Fruchart, C. Fievet, F.J. Gonzalez, J. Auwerx, Alterations in lipoprotein metabolism in peroxisome proliferatoractivated receptor alpha deficient mice. J. Biol. Chem. 272 (1997) 27307-27312.

[24] M. Cherkaoui Malki, P. Passilly, B. Jannin, M.-C. Clemencet, N. Latruffe, Carcinogenic aspect of xenobiotic molecules belonging to the peroxisome proliferaor family. Int. J. Mol. Med. 3 (1999) 163-168.

[25] B.F. Forman, P. Tontonoz, J. Chen, R.P. Brun, B.M. Spielgelman, R.M. Evans, 15 -deoxy- $\Delta^{12,14}$-prostaglandin $\mathrm{J}_{2}$ is a ligand for the adipocyte determination factor PPARgamma. Cell. 83 (1995) 803-812.

[26] R.A. Canuto, M. Ferro, R.A. Salvo, A.M. Bassi, A. Trombetta, M. Maggiora, G. Martinasso, R. Lindahl, G. Muzio, Increase in class 2 aldehyde dehydrogenase expression by arachidonic acid in rat hepatoma cells. Biochem J. 357 (2001) 811-8

[27] N. Di-Poi, L. Michalik, N.S. Tan, B. Desvergne, W. Wahli, The anti-apoptotic role of PPARbeta contributes to efficient skin wound healing. J. Steroid Biochem. Mol. Biol. 85 (2003) 257-65.

[28] L. Michalik, B. Desvergne, W. Wahli, Peroxisome proliferator-activated receptors beta/delta: emerging roles for a previously neglected third family member. Curr Opin Lipidol. 14 (2003) 129-35.

[29] R.A. Canuto, G. Muzio, A.M. Bassi, M. Maggiora, G. Leonarduzzi, R. Lindahl, M. Dianzani, M. Ferro, Enrichment with arachidonic acid increases the sensitivity of hepatoma cells to the cytotoxic effects of oxidative stress. Free Rad. Biol. Med. 18 (1995) 287-293

[30] G. Barbiero, F. Duranti, G. Bonelli, J.S. Amenta, F.M. Baccino, Intracellular ionic variations in the apoptotic death of $\mathrm{L}$ cells by inhibitors of cell cycle progression. Exp Cell Res. 17 (1995) 410-418.

[31] C. Jiang, A.T. Ting, Seed B PPAR $\alpha$ - agonist inhibits production of monocyte inflammatory cytokines. Nature. 391 (1998) 82-86.

[32] R. Shulte-Hermann, Adaptative liver growth induced by xenobiotic compounds: its nature and mechanism. Arch. Toxicol. S2 (1979) 113-12. 
[33] N.H. James, R.A. Roberts, Species difference in response to peroxisome proliferators correlates in vitro with induction of DNA synthesis rather than suppression of apoptosis. Carcinogenesis. 16 (1996) 1623-1632.

[34] M.S. El Kebbaj, M. Cherkaoui Malki, N. Latruffe, Properties of peroxisomes from jerboa. Eur J Cell Biol. 70 (1996) 150-156.

[35] C. Pacot, M. Petit, M. Rollin, Difference between guinea pig and rat in the liver peroxisomal response to equivalent plasmatic level of ciprofibrate. Arch Biochem. Biophys. 327 (1996) 181-188.

[36] P. Passilly, B. Jannin, S.J. Hassell, Human HepG2 and rat Fao hepatic-derived cell lines show different responses to ciprofibrate, a peroxisome proliferator: analysis by flow cytometry. Exp. Cell. Res. 223 (1996) 436-442.

[37] S. Ito, K. Yoshioka, T. Watanabe, Immunohistochemical demonstration of c-myc oncogene product and glutathione S-transferase (placental form) in rat hepatic preneoplastic lesions induced by diethylnitrosamine and clofibrate. Biomed. Res. 14 (1993) 345-351

[38] R.T. Miller, S.E. Glover, W.S. Stewart, Effect on the expression of c-met, c-myc and PPAR $\alpha$ in liver and liver tumors from rats chronically exposed to the hepatocarcinogenic peroxisome proliferator $\mathrm{Wy}-14,643$. Carcinogenesis. 17 (1996) 1337-1341.

[39- N. Latruffe, C. Pacot, P. Passilly, Peroxisomes and hepatotoxicity. Comp. Haematol. Int. 5 (1995) 189-195.

[40] B.J. Ledwith, T.E. Johnson, L.K. Wagner, Growth regulation by peroxisome proliferators: opposing activities in early and late G1. Cancer Res. 56 (1996) 3257-3264.

[41] J.M. Peters, T. Aoyama, R.C. Cattley, W. Nobumitsu, T. Hashimoto, F.J. Gonzalez, Role of peroxisome proliferator-activated receptor alpha in altered cell cycle regulation in mouse liver. Carcinogenesis. 19 (1998) 1989-1994

[42] C.Y. Fan, J. Pan, R. Hu, D. Lee, K.D.Kluckman, N. Usuda, I. Singh, A.V. Yeldandi, M.S. Rao, N. Maeda, J.K. Reddy, Hepatocellular and hepatic peroxisomal alterations in mice with a disrupted peroxisomal fatty acyl coenzyme A oxidase gene. J. Biol. Chem. 271 (1996) 25500-25506.

[43] C.Y. Fan, L. Pan, N. Usuda, A.V. Yeldandi, M.S. Rao, J.K Reddy, Seratohepatitis, spontaneous peroxisome proliferation and liver tumors in mice lacking peroxisomal fatty acid-CoA oxidase. J. Biol. Chem. 273 (1998) 15639-15645. 
[44] C.N. Palmer, M.H. Hsu, K.J. Griffin, J.L. Raucy, E.F. Johnson, Peroxisome proliferator activated receptor-alpha expression in human liver. Mol. Pharmacol. 53 (1998) 14-22.

[45] O. Braissant, F. Foufelle, C. Scotto, Differential expression of peroxisome proliferator-activated receptors (PPARs): tissue distribution of PPARalpha, beta/delta and -gamma in the adult rat. Endocrinology. 137 (1996) 354-366.

\section{Legend of figures}

Figure 1: Chemical structures of ciprofibrate and Wy 14,643

Figure 2: Effect of ciprofibrate on cell proliferation of hepatic derived cell, human HepG2 (A) and rat 7777 cells (B). Values are means \pm S.D. of 3 experiments. Ciprofibrate was dissolved in DMSO, at concentrations of $0.05,0.1,0.25,0.5$ or $1 \mathrm{mM}$. Cells were exposed to ciprofibrate for 4, 24 and 48 hours.

Means with different letters are statistically different $(\mathrm{P}<0.001)$ from one another as determined by ANOVA followed by the Newman-Keuls test.

C: control cells

Cipro: cells exposed to ciprofibrate at the indicated concentrations

Figure 3: Effect of ciprofibrate on the cell cycle phases in human HepG2 cells. Values are expressed as percentages of cells present in the $G_{0} / G_{1}, S$ and $G_{2} / M$ phases, and are means \pm S.D. of 3 experiments. S.D. (not reported in the figure) are less than $10 \%$.

C: control cells

Cipro: cells exposed to ciprofibrate at the indicated concentrations (in $\mathrm{mM}$ )

Figure 4: Effect of ciprofibrate on the cell cycle phases in rat 7777 cells . Values are expressed as percentages of cells present in the $G_{0} / G_{1}, S$ and $G_{2} / M$ phases, and are means \pm S.D. of 3 experiments. S.D. (not reported in the figure) are less than $10 \%$.

C: control cells

Cipro: cells exposed to ciprofibrate at the indicated concentrations (in $\mathrm{mM}$ )

Figure 5: Effect of ciprofibrate (Cipro) on pErk1,2 and Erk1,2 level on human HepG2 cells as revealed by western blot analysis.

Indications on treatment (dosage and length) are given in the results of the figure 
Figure 6: Effect of ciprofibrate (Cipro) on c-myc and PPARalpha level on human HepG2 (A) and rat 7777 (B) cells as revealed by western blot analysis, excepted to evidence the content of PPARalpha in HepG2 the immunoprecipitation method was used, since the Western Blot was not enough sensible.

Indications on treatment (dosage and length) are given in the results of the figure

Figure 7: Northern blot analysis of liver c-myc (Fig. 7A), AOX and PPAR $($ Fig. 7B) mRNA expression in wild-type (+/+) and PPARalpha-null (-/-) mice. Fold increase in presence of $\mathrm{Wy} 14,643(\mathrm{Wy})$ represents increase in relative hybridization signal (\% beta-actin) as compared to respective control (C). The blot is representative of three different blotting

\section{Tables}

Table 1 - Percentage of apoptotic cells in human and rat hepatoma cells after treatment with ciprofibrate.

\begin{tabular}{|c|c|c|c|c|c|c|}
\hline \multirow{2}{*}{ CELLS } & \multicolumn{2}{|c|}{ NONE } & \multicolumn{2}{c|}{$0.5 \mathrm{mM}$ CIPROFIBRATE } & \multicolumn{2}{c|}{$1 \mathrm{mM}$ CIPROFIBRATE } \\
\cline { 2 - 7 } & $24 \mathrm{~h}$ & $48 \mathrm{~h}$ & $24 \mathrm{~h}$ & $48 \mathrm{~h}$ & $24 \mathrm{~h}$ & $48 \mathrm{~h}$ \\
\hline \multirow{2}{*}{ HepG2 } & $3.41 \pm 0.35 \mathrm{a}$ & $3.02 \pm 0.26 \mathrm{a}$ & $2.82 \pm 0.40 \mathrm{a}$ & $2.56 \pm 0.33 \mathrm{a}$ & $2.99 \pm 0.45 \mathrm{a}$ & $7.09 \pm 0.56 \mathrm{~b}$ \\
\hline 7777 & $0.39 \pm 0.09 \mathrm{a}$ & $6.52 \pm 0.76 \mathrm{~b}$ & $4.89 \pm 0.67 \mathrm{~b}$ & $29.42 \pm 2.77 \mathrm{c}$ & $7.01 \pm 1.89 \mathrm{~d}$ & $36.99 \pm 4.91 \mathrm{c}$ \\
\hline
\end{tabular}

Data obtained from flow cytometry analysis are expressed as percentage of apoptotic cells respect to total cells and represent means \pm S.D. of three experiments.

Human HepG2 hepatoblastoma cells were seeded $\left(50000\right.$ cells $\left./ \mathrm{cm}^{2}\right)$ and maintained in MEM medium plus $2 \mathrm{mM}$ glutamine, $1 \%$ antibiotic/antimycotic solution and $10 \%$ foetal bovine serum. Rat hepatoma 7777 cells were seeded $\left(20000\right.$ cells $\left./ \mathrm{cm}^{2}\right)$ and maintained in DMEM/F12 medium plus $2 \mathrm{mM}$ glutamine, $1 \%$ antibiotic/antimycotic solution and $10 \%$ newborn calf serum. $24 \mathrm{~h}$ after cell seeding, HepG2 and 7777cells were treated with ciprofibrate, dissolved in DMSO, at concentrations of 0.5 or $1 \mathrm{mM}$ and harvested at 24 and $48 \mathrm{~h}$. 
20

Figure 1

Hypolipidaemic agent

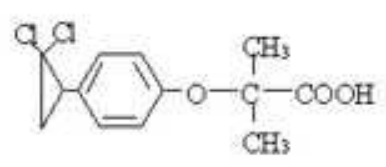

Cipnoficrate (Cipno)

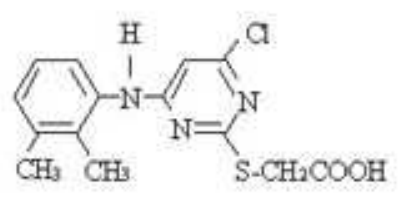

Wy-14,643 
Figure 2

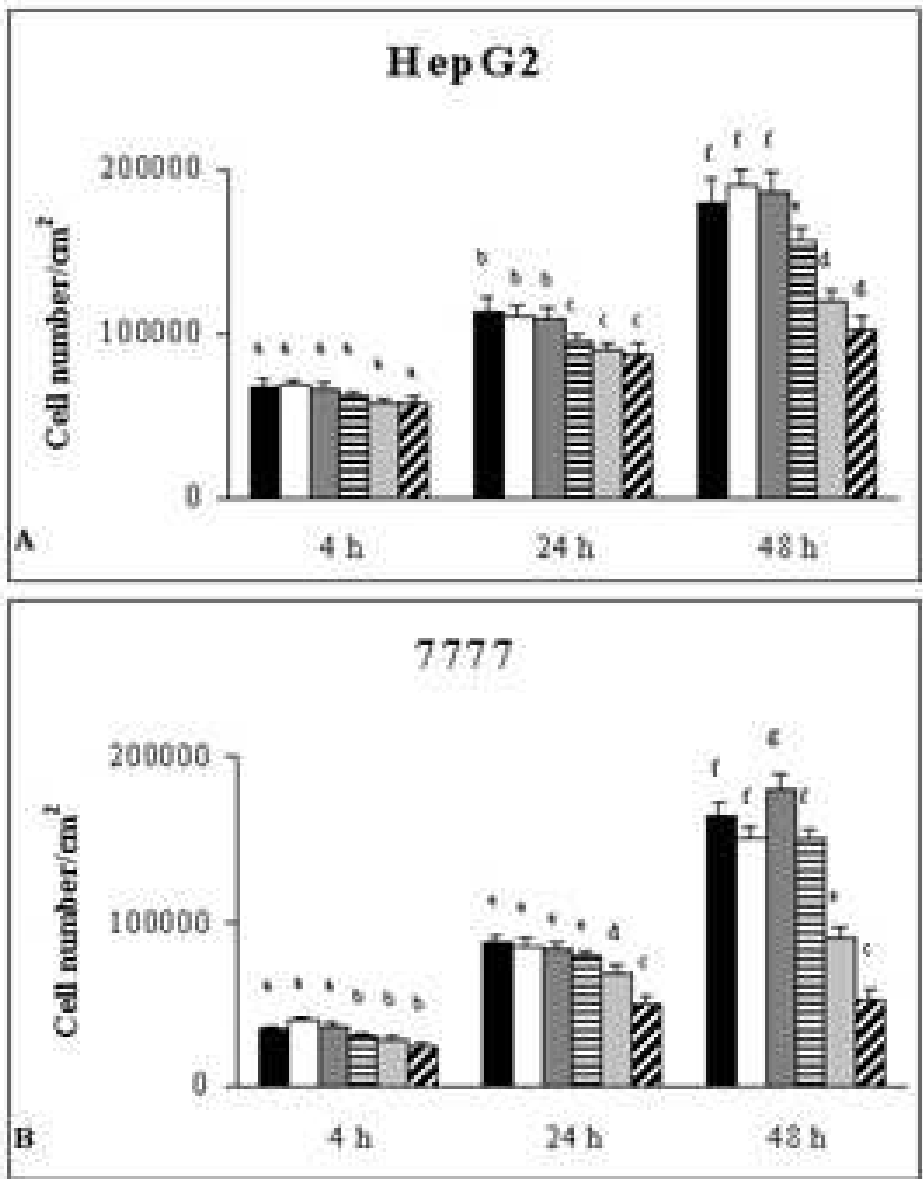

- $\mathrm{C} \square 0.05 \mathrm{mM} \mathrm{C}_{\text {ipro }} \square 0.1 \mathrm{mM} \mathrm{C}_{\text {ipto }}$

日 $0.25 \mathrm{mM}$ Cipro 口 $0.5 \mathrm{mM}$ Cipro $21 \mathrm{mM}$ Cipro 
Figure 3 - Hep G2 hepatom a cells
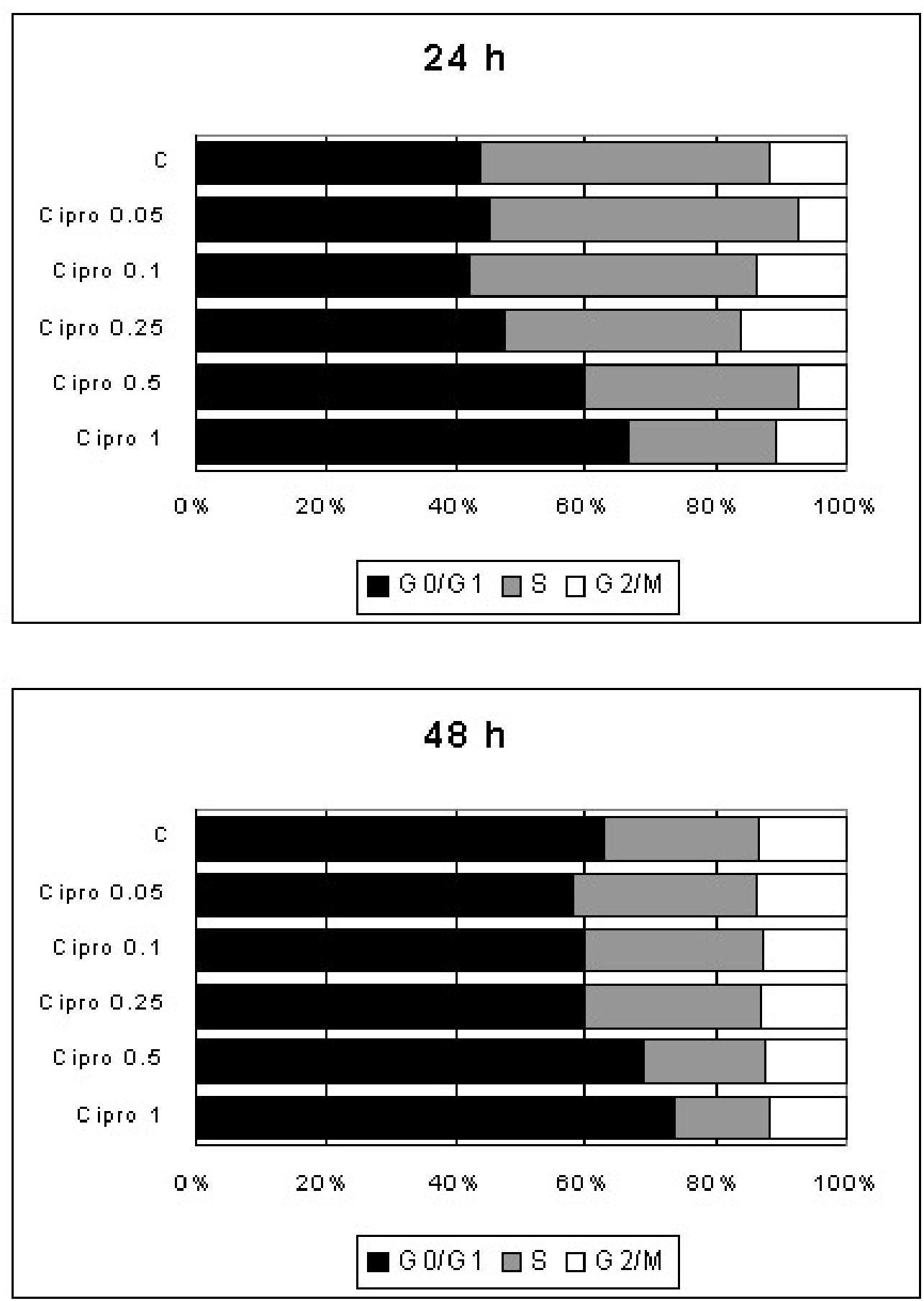
Figure $4-7777$ hepatoma cells
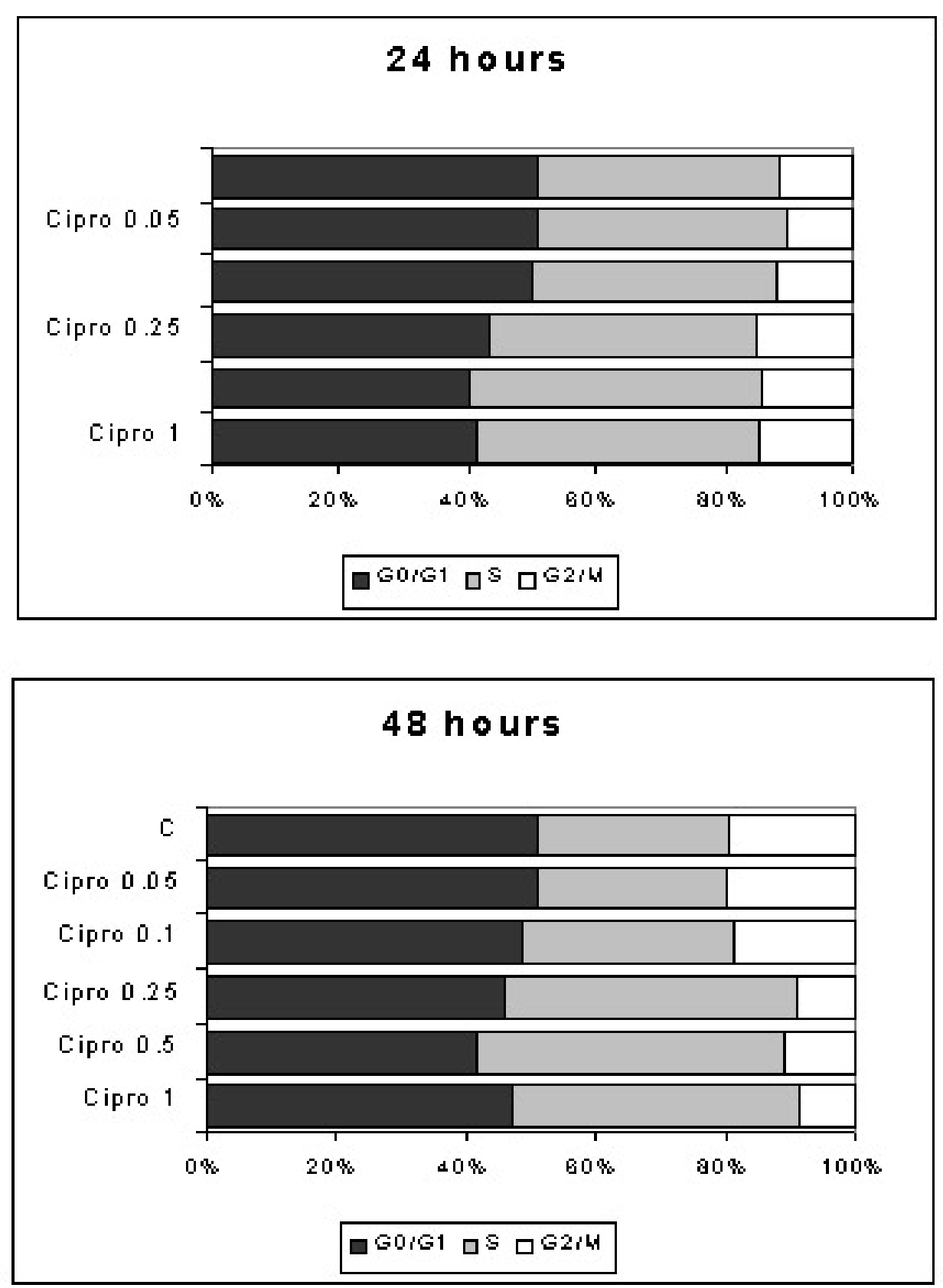
Figure 5

\section{Human HepG2 cells}

\begin{tabular}{|c|c|c|c|c|c|c|}
\hline \multicolumn{3}{|c|}{$24 \mathrm{~h}$} & \multicolumn{3}{|c|}{$48 \mathrm{~h}$} & \\
\hline 0 & 0.5 & 1 & 0 & 0.5 & 1 & $\operatorname{cipro}(\mathrm{mM})$ \\
\hline 100 & 42 & 28 & 100 & 11 & 0 & \\
\hline$=$ & $=$ & 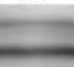 & $=$ & 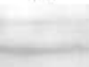 & & pERK 1,2 \\
\hline
\end{tabular}

\begin{tabular}{|c|c|c|c|c|c|}
\hline 100 & 108 & 104 & 100 & 115 & 110 \\
\hline
\end{tabular}


Figure 6

A Human HepG2 cells

\begin{tabular}{|c|c|c|c|c|c|c|}
\hline \multicolumn{3}{|c|}{$24 \mathrm{~h}$} & \multicolumn{3}{|c|}{$48 \mathrm{~h}$} & \\
\hline 0 & 0.5 & 1 & 0 & 0.5 & 1 & cipro (mM) \\
\hline$=$ & $-\infty$ & $-\infty$ & 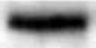 & 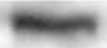 & -0 & c-myc \\
\hline 100 & 80 & 70 & 100 & 62 & 45 & \\
\hline
\end{tabular}

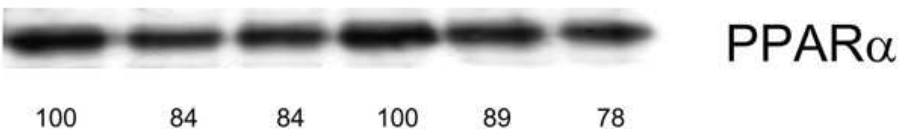

$\begin{array}{llllll}100 & 84 & 84 & 100 & 89 & 78\end{array}$

B Rat 7777 cells

\begin{tabular}{|c|c|c|c|c|c|c|}
\hline \multicolumn{3}{|c|}{$24 \mathrm{~h}$} & \multicolumn{3}{|c|}{$48 \mathrm{~h}$} & \multirow[b]{2}{*}{ cipro (mM) } \\
\hline 0 & 0.5 & 1 & 0 & 0.5 & 1 & \\
\hline wis & nemer & $=$ & $4-3=$ & $=$ & veneser & c-myc \\
\hline 100 & 188 & 242 & 100 & 250 & 275 & \\
\hline- & in & W & - & $=$ & $\dot{\sim}$ & PPAR \\
\hline 100 & 68 & 50 & 100 & 590 & 840 & \\
\hline
\end{tabular}


Figure 7
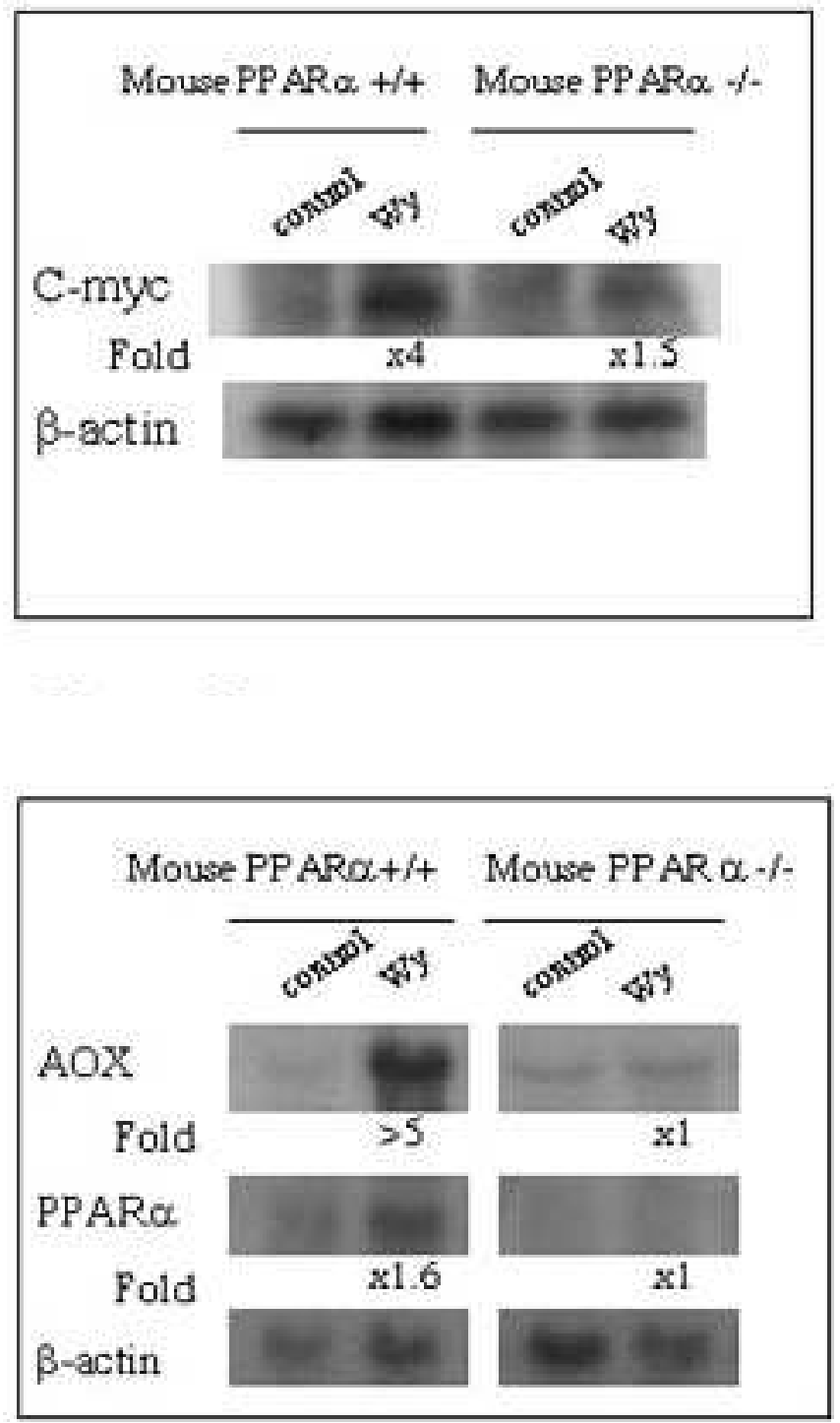